\title{
Biodistribution of gold nanoparticles in mouse lung following intratracheal instillation
}

\author{
Evaldas Sadauskas ${ }^{1,2}$, Nicklas Raun Jacobsen ${ }^{2}$, Gorm Danscher ${ }^{1}$, \\ Meredin Stoltenberg ${ }^{1}$, Ulla Vogel ${ }^{2,3,4}$, Agnete Larsen ${ }^{1}$, Wolfgang Kreyling ${ }^{5}$ and \\ Håkan Wallin*2,6
}

\begin{abstract}
Address: ${ }^{1}$ Department of Neurobiology, Institute of Anatomy, University of Aarhus, Building 1233/1234, Wilhelm Meyers Allé, DK-8000 Aarhus, Denmark, ${ }^{2}$ National Research Centre for the Working Environment, Lersø Parkallé 105, DK-2100 Copenhagen, Denmark, ${ }^{3}$ National Food Institute, Technical University of Denmark, Mørkhøj Bygade 19, DK-2860 Søborg, Denmark, ${ }^{4}$ Institute for Science, Systems and Models, University of Roskilde, DK-4000 Roskilde, Danmark, ${ }^{5}$ Institute of Lung Biology and Disease, Helmholtz Zentrum München, German Research Center for Environmental Health (GmbH), Ingolstaedter Landstr. 1, 85764 Neuherberg/Munich, Germany and 'Institute of Public Health, Copenhagen University, Øster Farimagsgade 5, DK-1014 Copenhagen, Denmark
\end{abstract}

Email: Evaldas Sadauskas - esad@ana.au.dk; Nicklas Raun Jacobsen - nrj@nrcwe.dk; Gorm Danscher - gd@neuro.au.dk; Meredin Stoltenberg - ms@neuro.au.dk; Ulla Vogel - ulbvo@food.dtu.dk; Agnete Larsen - al@neuro.au.dk; Wolfgang Kreyling - kreyling@gsf.de; Håkan Wallin* - hwa@nrcwe.dk

* Corresponding author

Published: 20 November 2009

Chemistry Central Journal 2009, 3:16 doi:10.1186/1752-153X-3-16
Received: 10 February 2009

Accepted: 20 November 2009

This article is available from: http://journal.chemistrycentral.com/content/3/1/16

(C) 2009 Sadauskas et al

\begin{abstract}
Background: The fate of gold nanoparticles, 2, 40 and $100 \mathrm{~nm}$, administered intratracheally to adult female mice was examined. The nanoparticles were traced by autometallography (AMG) at both ultrastructural and light microscopic levels. Also, the gold content was quantified by inductively coupled plasma mass spectrometry (ICP-MS) and neutron activation analysis (NAA). The liver is the major site of deposition of circulating gold nanoparticles. Therefore the degree of translocation was determined by the hepatic deposition of gold. Mice were instilled with 5 intratracheal doses of gold nanoparticles distributed over a period of 3 weeks and were killed 24 $\mathrm{h}$ after the last dose. One group of mice were given a single intratracheal dose and were killed after I h.
\end{abstract}

Results: The instilled nanoparticles were found in lung macrophages already I $\mathrm{h}$ after a single instillation. In mice instilled treated repeatedly during 3 weeks, the load was substantial. Ultrastructurally, AMG silver enhanced gold nanoparticles were found in lysosome-/endosome-like organelles of the macrophages and analysis with AMG, ICP-MS and NAA of the liver revealed an almost total lack of translocation of nanoparticles. In mice given repeated instillations of $2 \mathrm{~nm}$ gold nanoparticles, I.4\% (by ICP-MS) to I.9\%。 (by NAA) of the instilled gold was detected in the liver. With the $40 \mathrm{~nm}$ gold, no gold was detected in the liver (detection level $2 \mathrm{ng}, 0.1 \%$ ) except for one mouse in which $3 \%$ of the instilled gold was found in the liver. No gold was detected in any liver of mice instilled with $100 \mathrm{~nm}$ gold (detection level $2 \mathrm{ng}, 0.1 \%$ ) except in a single animal with $0.39 \%$ 。 of the dose in the liver.

Conclusion: We found that that: (I) inert gold nanoparticles, administered intratracheally are phagocytosed by lung macrophages; (2) only a tiny fraction of the gold particles is translocated into systemic circulation. (3) The translocation rate was greatest with the $2 \mathrm{~nm}$ gold particles. 


\section{Background}

Epidemiological studies have reported associations between episodes of increased air pollution with particulate matter and adverse health effects in susceptible individuals [1-6]. It has been suggested, that the nanosized particles are the most dangerous fraction [7]. Air-borne nanoparticles (ultrafine particles) have been found to penetrate into the systemic circulation following inhalation $[8,9]$. Additionally, there is experimental evidence that respiratory exposure to nanoparticles may promote thrombosis $[10,11]$. It has been suggested that lung injury increases the degree of the nanoparticle translocation [12]. For a better understanding of the potential hazards of inhaled nanoparticles it is important to establish whether nanoparticles are translocated, i.e. transported through the alveolar barrier to the systemic circulation. It is known, that nanoparticles, once in the lungs, can be recognized and phagocytosed by lung macrophages [13]. The degree of translocation seems to be dependent on particle size, chemical composition, shape, electrical charge etc [14]. Smaller particles have been shown to more easily penetrate through the alveolar barrier than larger ones $[14,15]$. Once in the systemic circulation, the nanoparticles can reach extrapulmonary organs like liver, spleen, etc $[8,9,16]$. Translocation of inhaled ultrafine particles into the brain via the olfactory system has also been reported [16-18].

As a model we chose gold nanoparticles which are considered nontoxic [19] and can be traced histochemically by AMG, even ultrastructurally. Such gold nanoparticles are already in use for diagnostics, therapy and research [2024]. Takenaka and coworkers treated rats with an aerosol of gold nanoparticles, 5-8 $\mathrm{nm}$ in diameter, produced by a spark generator. They observed accumulation of such particles in the pulmonary macrophages and epithelial cells and a low degree of systemic translocation [25]. SemmlerBehnke and coworkers demonstrated that intratracheally instilled $18 \mathrm{~nm}$ gold nanoparticles are retained in the rat lungs whereas $1.4 \mathrm{~nm}$ nanoparticles are being translocated in significant amounts to the secondary organs [26]. We hypothesized that 40 and $100 \mathrm{~nm}$ gold nanoparticles would be retained in lung macrophages and translocated to a minor degree while according to present ideas; $2 \mathrm{~nm}$ particles would be translocated and subsequently accumulate in the liver. We have previously reported that 40 $\mathrm{nm}$ colloidal gold nanoparticles are easily detected in liver after intravenous injection [27] and that the liver accumulates and retains most of the dose for a long period of time [28]. We therefore assume that if gold nanoparticles are translocated through alveolar epithelium they will be accumulated primarily in the liver.

The objective of the present study was to evaluate the extent of gold nanoparticle translocation from the lungs into the systemic circulation. As a model for evaluation of whether nanoparticles penetrate lung epithelium we instilled gold nanoparticles, sized 2, 40 and $100 \mathrm{~nm}$ in mice intratracheally, and examined the lungs and the liver by optical and electron microscopy. We wanted to establish the significance of size in translocation and to identify where and in which cells the nanoparticles accumulated using LM and EM autometallography (AMG). AMG enables tracing of gold nanoparticles in morphologically intact tissue by silver enhancement of the individual nanoparticles $[20,29]$. To add the quantitative dimension the tissues were further analyzed by ICP-MS and neutron activation (NAA).

\section{Experimental Gold nanoparticles}

Gold nanoparticles from Fitzgerald Industries Inc, USA had been produced by citrate reduction. They were negatively charged, monodisperse and spherical. The $2 \mathrm{~nm}$ contained $15 \times 10^{13}$ particles $/ \mathrm{ml}(12.1 \mu \mathrm{g})$, the $40 \mathrm{~nm} 9 \times$ $10^{10} / \mathrm{ml}(58.2 \mu \mathrm{g})$ and the $100 \mathrm{~nm} 6 \times 10^{9} / \mathrm{ml}(60.1 \mu \mathrm{g})$.

\section{The animal model}

The study was performed in accordance with Danish law and guidelines for animal welfare. A total of 44 adult female C57BL mice were used. The mice were 8-12 weeks old with a body of weight of 18-21 grams. The mice were housed in plastic cages under the following conditions: 12 h light/dark cycle, $22+/-2{ }^{\circ} \mathrm{C}$ and $50+/-10 \%$ relative humidity. Food (Altromin No. 1314, Altromin Spezialfutterwerke, Germany) and tap water were available ad libitum.

\section{Single instillations}

Eight mice were divided into 3 experimental groups and 1 control group, 2 mice in each. Two mice were instilled intratracheally with $50 \mu \mathrm{l}$ 2, 40 or $40 \mathrm{~nm}$ gold nanoparticles and were killed after $1 \mathrm{~h}$. Two control mice were instilled with distilled water and treated identically. These 8 animals were used for histochemical analysis with the AMG method. In adition, 4 mice were used to NAA analysis. Two of them were given $50 \mu \mathrm{l} 40 \mathrm{~nm}$ gold nanoparticles and the other 2 were instilled with distilled water and served as controls. These animals were sacrificed after 1 day and analyzed with NAA.

\section{Repeated instillations}

Twenty mice were divided into 3 experimental groups and 1 control group, 5 mice in each. Five mice were given 50 $\mu \mathrm{l}$ of a $2 \mathrm{~nm}$ gold suspension, similarly 5 mice were given $40 \mathrm{~nm}$ gold and 5 mice $100 \mathrm{~nm}$ gold. The 5 mice served as controls and were exposed to distilled water only. These 20 mice were intratracheally instilled 5 times during a period of 3 weeks and sacrificed 24 hours after the last instillation. Tissues from these 20 mice were used both for 
histochemical analysis with AMG and quantitative analysis with the ICP-MS method. In a second experiment 12 mice were used to NAA analysis. Six mice were given $2 \mathrm{~nm}$ gold nanoparticles and the other 6 animals served as controls. The livers of these animals were analyzed with NAA. The neutron activation dose was greater in this experiment resulting in a lower detection level (see NNA section).

\section{Transcardial perfusion}

The mice were anesthetized with sodium pentobarbital (50 mg/kg body weight) and transcardially perfused at $120 \mathrm{~mm} \mathrm{Hg}$ with 3\% buffered glutaraldehyde for 5 min (1 min of rapid flow followed by 4 min of reduced flow 5-10 $\mathrm{ml} / \mathrm{min}$ ). The lungs and liver were taken out immediately after perfusion and placed in the 3\% buffered glutaraldehyde solution. In the "repeated instillations" groups, the median lobe of the liver was used for histological analysis. The lobe was divided at the gall bladder bifurcature. The right part of the lobe was used for paraffin sections whereas the left part was used for Epon sections and electron microscopy. The animals that were used for quantitative analysis with neutron activation were sacrificed by cervical dislocation and were not transcardialy perfused.

\section{Tissue processing}

The tissue selected for paraffin sectioning was dehydrated and paraffin embedded. The tissue was then cut into $8 \mu \mathrm{m}$ thick sections. In all mice the same part of the liver was used for paraffin embedding, i.e., the right part of the median lobe, divided at the gall bladder bifurcature. This block of the liver measures approximately $10 \times 5 \times 5 \mathrm{~mm}$. Seven to ten sections were cut from each mouse organ The sectioning was performed with random start, and every 125 th section was selected for analysis. These randomly selected sections were then AMG developed for 60 min and counterstained with toluidine blue. Tissue to be embedded in Epon blocks was cut in approximately $2 \times 2$ $\times 2 \mathrm{~mm}$ blocks with a razorblade or scalpel and rinsed in $0.10 \mathrm{M}$ phosphate buffer ( $\mathrm{pH} 7.4$ ) for $2 \times 5 \mathrm{~min}$, then dehydrated in graded ethanol solutions and embedded in Epon. Semithin sections $(3 \mu \mathrm{m})$ were cut with an ultramicrotome (Leica EM UC6, Leica Microsystems GmbH, Germany) and placed on glass slides before being AMG developed. After light microscopic analyses, selected sections were re-embedded on top of a blank Epon block and trimmed to include only the regions of interest. Thereafter, ultrathin sections were cut and counterstained with lead citrate and uranyl acetate before electron microscopic analysis on a Philips Morgagni 268D, FEI, USA.

\section{AMG development}

The AMG developer consisted of a $60 \mathrm{ml}$ gum arabic solution and $10 \mathrm{ml}$ sodium citrate buffer $(25.5 \mathrm{~g}$ of citric acid $\cdot 1 \mathrm{H}_{2} \mathrm{O}+23.5 \mathrm{~g}$ sodium citrate $\cdot 2 \mathrm{H}_{2} \mathrm{O}$ to $100 \mathrm{ml}$ distilled water). Immediately before use $15 \mathrm{ml}$ reducing agent $(0.85 \mathrm{~g}$ of hydroquinone dissolved in $15 \mathrm{ml}$ distilled water at $40^{\circ} \mathrm{C}$ ) and $15 \mathrm{ml}$ of a solution containing silver ions $\left(0.12 \mathrm{~g}\right.$ silver lactate in $15 \mathrm{ml}$ distilled water at $\left.40^{\circ} \mathrm{C}\right)$ were added, and the AMG developer was thoroughly stirred [28]. The glass slides were put in a jar filled with the AMG developer and placed in a water bath at $26^{\circ} \mathrm{C}$. During AMG development an electric device shook the jars gently. The entire set-up was covered with a dark hood while the developing took place. After 60 minutes the AMG development was stopped by rinsing the slices in water and afterwards replacing the developer with a 5\% sodium thiosulphate solution for $10 \mathrm{~min}$ (the AMG stop bath solution). The jars were then placed under gently running water for 20 minutes.

\section{Post AMG treatment}

The sections from the different sources were counterstained with a $0.1 \%$ aqueous toluidine blue solution $(\mathrm{pH}$ 4.0 ), dehydrated in alcohol to xylene, and ultimately embedded in DEPEX and covered with a cover glass. Black/brown silver grains represented silver-encapsulated gold nanoparticles. All procedures and protocols have previously been described in details [28].

\section{Inductively coupled plasma mass spectroscopy (ICP-MS)}

The median lobe, comprising about one third of the liver mass in mice, was used for morphological observations while the ICP-MS analysis was performed on the remaining part of the liver. Water was purified by reverse osmosis (Elix 100, Millipore, Bedford, MA, USA) and a Milli-Q system (Millipore). Polystyrene test tubes (Sarstedt, Numbrecht, Germany) were washed in tenfold diluted nitric acid (65\% analytical grade; Merck, Darmstadt, Germany) and stored containing $0.7 \mathrm{M}$ nitric acid purified by sub-boiling distillation in quartz still (Heraeus, Hanau, Germany). Digestion vessels were cleaned before use by adding 7.5 $\mathrm{ml}$ hydrochloric acid (30\% p.a. plus, Fluka, Buchs, Switzerland) and $2.5 \mathrm{ml}$ nitric acid and performing a wash cycle in the microwave oven (Mars 5, CEM Corporation, Matthews, NC, USA) at $300 \mathrm{~W}$ for $30 \mathrm{~min}$.

Each sample was transferred to a freshly cleaned and rinsed microwave digestion vessel. Then $5 \mathrm{ml}$ of sub-boiling distilled nitric acid and $0.5 \mathrm{ml}$ hydrogen peroxide (30\% p.a., Riedel-de-Haen, Seelze, Germany) was added, and the samples were digested for $60 \mathrm{~min}$ at $600 \mathrm{~W}$. After cooling the vessels were opened, $1 \mathrm{ml}$ hydrochloric acid was added to each vessel, and a further 10 min digestion at $600 \mathrm{~W}$ was carried out. Upon cooling the clear digest was transferred to a polystyrene test tube and diluted to 10 $\mathrm{ml}$ with high purity water. Prior to analysis the digests, sample preparation blanks, and calibrants were diluted appropriately and thallium was added to a concentration of $25 \mu \mathrm{g} / \mathrm{l}$ as internal standard. A certified gold standard solution from Ultra Scientific (Kingstown, RI, USA) was 
serially diluted to prepare calibrant solutions. Analyses of the diluted sample digests were carried out using inductively coupled plasma - sector field mass spectrometry (Element, Thermo Scientific, Bremen, Germany). The ICP-MS analysis was performed by ALS Scandinavia AB, Luleå, Sweden.

\section{Neutron activation analysis}

Neutron activation analysis (NAA) was performed at the Nuclear Research Reactor of the Helmholtz Center Berlin, Germany. The liver samples were freeze-dried and irradiated in an O-ring sealed test tube at a reproducibly achievable position within the reactor tank. For calibration purposes a pre-weighed gold standard was irradiated at the same location for the same time; from its measured radioactivity the Au mass in the liver samples was analyzed. For validation of the NAA method different amounts of gold was added to livers of untreated mice. In the first experiment the detection limit was $3.9 \mathrm{ng}$. In the second experiment the samples were irradiated with a greater dose of neutrons for obtaining a lower detection limit. The slope of the regression line of added versus detected gold was 1.013 and the detection limit was about 1 ng gold.

\section{Results}

\section{Autometallographic analysis}

Single instillations

In all 6 mice instilled intratracheally with a single dose of 2, 40 or $100 \mathrm{~nm}$ gold nanoparticles, gold was detected in the macrophages of the lungs after $1 \mathrm{~h}$. Ultrastructurally, the nanoparticles were located inside lysosome-like vesicles. AMG stained sections from control animals were all void of gold (Fig. 1C).

\section{Repeated instillations}

20 animals were instilled intratracheally with gold nanoparticles 5 times during a period of 3 weeks. Initially, there were 4 groups consisting of 5 animals in each. These animals were exposed to 2, 40, $100 \mathrm{~nm}$ gold nanoparticles and distilled water, respectively. However, only 16 animals survived the experiment: 3 animals exposed to $2 \mathrm{~nm}$ gold nanoparticles and 1 animal exposed to $40 \mathrm{~nm}$ particles died during the instillation. All the animals exposed to $100 \mathrm{~nm}$ gold nanoparticles or distilled water only survived. The distribution of gold in the lungs of the animals treated by multiple instillations was identical to the pattern seen in the single instillation group although the AMG staining intensity and the amount of loaded cells were higher. Nanoparticles of all three sizes were retained in the lungs (Fig. 1A, B, D, E). The instilled gold nanoparticles were located in lysosome-like organelles in lung macrophages (Fig. 1D, E). The nanoparticles were present in macrophages, both those attached to the alveolar wall and inside the interstitium. However, we could not deter- mine, whether the nanoparticles were located only in the macrophages or both in the macrophages and epithelial cells. Careful microscopic analysis of randomly selected cryosections of the liver revealed no sign of gold nanoparticles in the exposed animals. Only in one animal, exposed to multiple instillations of $40 \mathrm{~nm}$ gold nanoparticles, AMG enhanced gold nanoparticles were seen in a few Kupffer cells.

\section{Quantitative analysis with Inductively Coupled Plasma Mass Spectrometry}

The livers of mice treated with multiple instillations were analyzed with ICP-MS (Table 1). The two mice that survived 5 instillations with $2 \mathrm{~nm}$ particles showed traces of gold in the liver, 4 and 4.1 ng gold in each. The total gold mass which was given to these 2 mice during a period of 3 weeks was $3025 \mathrm{ng}$ of pure gold per animal and the amount of gold traced in the liver was 1.32 and $1.36 \%$ of the total dose given. In 1 animal, receiving $40 \mathrm{~nm}$ particles, $43.4 \mathrm{ng}$ of gold was detected in the liver which is $3 \%$ of the total $14550 \mathrm{ng}$ gold given. The amount of gold in the liver of the remaining three $40 \mathrm{~nm}$ gold mice was below detection level. In 1 animal, exposed to $100 \mathrm{~nm}$ particles, $5.8 \mathrm{ng}$ of gold was traced in the liver which is $0.39 \%$ of the total $15 \mu$ gold given. In the remaining 4 mice, given $100 \mathrm{~nm}$ gold nanoparticles, the amount of gold in the liver was below the detection limit. No gold was detected in all 5 control mice treated with distilled water.

\section{Neutron activation analysis (NAA)}

Two mice of the four mice included in the NAA study were instilled with a dose $2.9 \mu \mathrm{g} 40 \mathrm{~nm}$ gold nanoparticles. No gold was detected in the liver, neither in the experimental animals nor in the controls. The detection limit was 3.9 $n$, which is $<2 \%$ of the instilled amount of gold. In the second experiment 6 mice were instilled intratracheally with $2 \mathrm{~nm}$ gold and 6 mice were instilled with distilled water to examine whether the gold instillations were toxic and to quantify the gold with greater sensitivity. The neutron activation dose was greater in this experiment resulting in a lower detection level, i.e. $1 \mathrm{ng}$. All 6 mice were unaffected by the gold instillations with the $2 \mathrm{~nm}$ gold. One day after the 5th instillation the gold content was determined only by NAA. The livers of the mice contained $5.8 \pm 1.8 \mathrm{ng}$ (mean \pm standard deviation). Because the mice were instilled with an accumulated dose of $3.03 \mu \mathrm{g}$ gold, $1.9 \pm 0.6 \%$ of the instilled $2 \mathrm{~nm}$ gold particles had accumulated in the liver 1 day after the 5th injection.

\section{Discussion}

When nanoparticles are inhaled and deposited in the lung a fraction of them are being phagocytozed by alveolar macrophages [13]. A part of the particles are removed from the lung by the mucociliary escalator, but a part is 

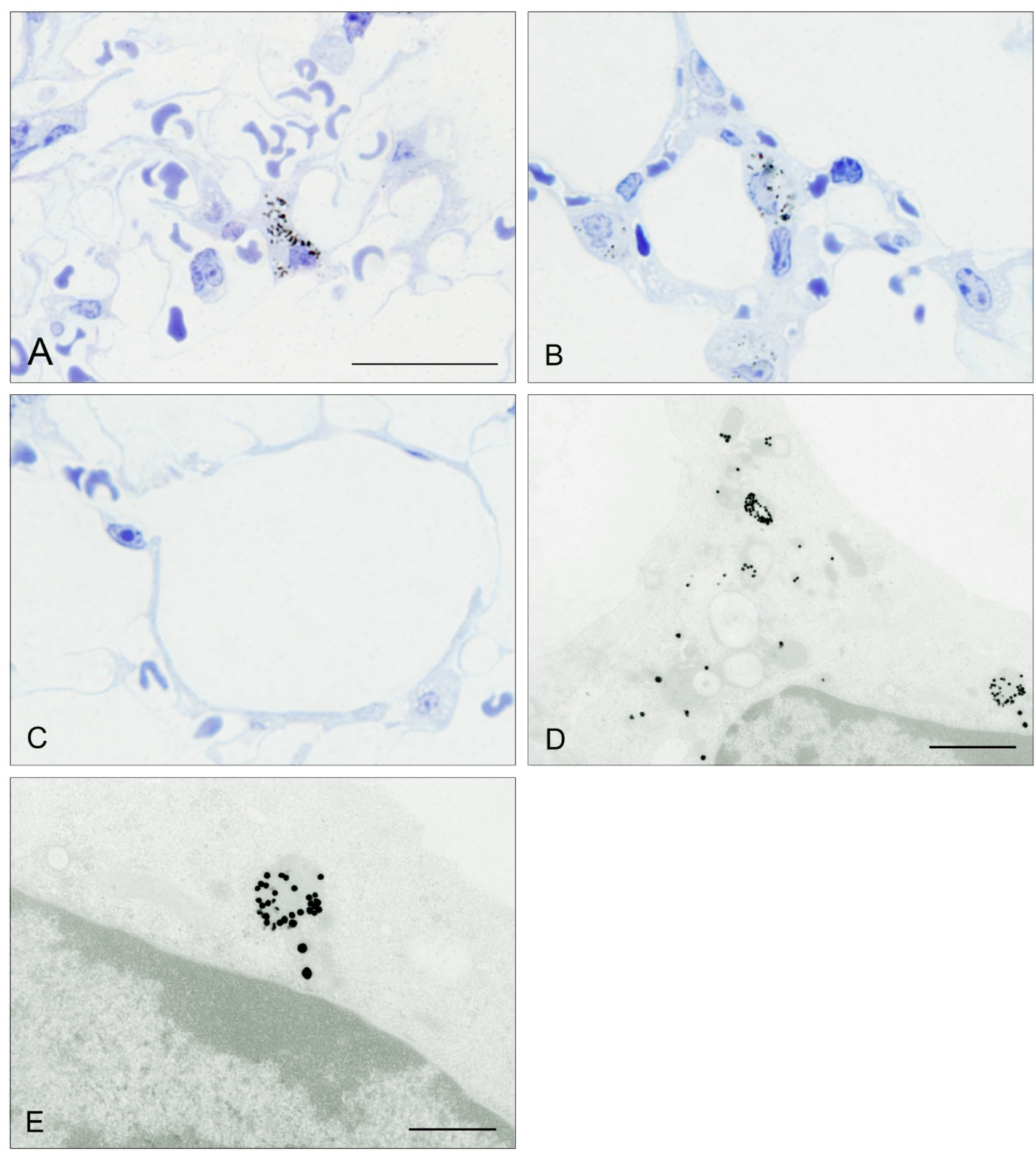

Figure I

Light and electron micrographs showing AMG enhanced gold nanoparticles in the lungs of mice following intratracheal instillations. A and B represent $L M$ section taken from the animals exposed to multiple intratracheal instillations with gold, $40 \mathrm{~nm}$ and $100 \mathrm{~nm}$ nanoparticles, respectively. AMG enhanced gold nanoaparticles are located inside lung macrophages resembling cells. $C$ represents a control, void of AMG staining. D and $E$ are EM picture representing the animals exposed to multiples instillations with $40 \mathrm{~nm}$ gold nanoparticles. Gold is located inside lysosome/endosome-like vesicles. Scalebars: $20 \mu \mathrm{m}$ in A - C; I $\mu \mathrm{m}$ in D; $500 \mathrm{~nm}$ in $\mathrm{E}$. 
Table I: Gold amount in the mouse liver following five intratracheal instillations detected with ICPMS.

\begin{tabular}{|c|c|c|c|c|}
\hline Animal number & $\begin{array}{l}\text { Particles used for } \\
\text { instillations }\end{array}$ & $\begin{array}{l}\text { Total amount/volume } \\
\text { given }\end{array}$ & $\begin{array}{l}\text { Amount of gold traced } \\
\text { in the liver }\end{array}$ & $\begin{array}{l}\text { Level of the gold in the liver } \\
\text { compared with the total } \\
\text { amount given }\end{array}$ \\
\hline I. & $2 \mathrm{~nm} \mathrm{Au}$ & $3025 \mathrm{ng}$ & $4 \mathrm{ng}$ & $1.3 \%$ \\
\hline 2. & $2 \mathrm{~nm} \mathrm{Au}$ & $3025 \mathrm{ng}$ & $4.1 \mathrm{ng}$ & $1.4 \%$ \\
\hline 3. & $40 \mathrm{~nm} \mathrm{Au}$ & $14550 \mathrm{ng}$ & $<2 \mathrm{ng}$ & 0 \\
\hline 4. & $40 \mathrm{~nm} \mathrm{Au}$ & $14550 \mathrm{ng}$ & $<2 \mathrm{ng}$ & 0 \\
\hline 5. & $40 \mathrm{~nm} \mathrm{Au}$ & $14550 \mathrm{ng}$ & $<2 \mathrm{ng}$ & 0 \\
\hline 6. & $40 \mathrm{~nm} \mathrm{Au}$ & $14550 \mathrm{ng}$ & $43.4 \mathrm{ng}$ & $3 \%$ \\
\hline 7. & $100 \mathrm{~nm} \mathrm{Au}$ & $15025 \mathrm{ng}$ & $5.8 \mathrm{ng}$ & $0.39 \%$ \\
\hline 8. & $100 \mathrm{~nm} \mathrm{Au}$ & $15025 \mathrm{ng}$ & $<2 \mathrm{ng}$ & 0 \\
\hline 9. & $100 \mathrm{~nm} \mathrm{Au}$ & $15025 \mathrm{ng}$ & $<2 \mathrm{ng}$ & 0 \\
\hline 10. & $100 \mathrm{~nm} \mathrm{Au}$ & $15025 \mathrm{ng}$ & $<2 \mathrm{ng}$ & 0 \\
\hline II. & $100 \mathrm{~nm} \mathrm{Au}$ & $15025 \mathrm{ng}$ & $<2 \mathrm{ng}$ & 0 \\
\hline 12. & $\mathrm{H}_{2} \mathrm{O}$ & $250 \mu \mathrm{l}$ & $<2 \mathrm{ng}$ & \\
\hline 13. & $\mathrm{H}_{2} \mathrm{O}$ & $250 \mu \mathrm{l}$ & $<2 \mathrm{ng}$ & \\
\hline 14. & $\mathrm{H}_{2} \mathrm{O}$ & $250 \mu \mathrm{l}$ & $<2 \mathrm{ng}$ & \\
\hline 15. & $\mathrm{H}_{2} \mathrm{O}$ & $250 \mu \mathrm{l}$ & $<2 \mathrm{ng}$ & \\
\hline 16. & $\mathrm{H}_{2} \mathrm{O}$ & $250 \mu \mathrm{l}$ & $<2 \mathrm{ng}$ & \\
\hline
\end{tabular}

translocated across the alveolar epithelium [30-32]. Translocation of nanoparticles through the alveolar barrier, if it takes place, has been speculated to depend primarily on endocytotic-exocytotic activity and less so by paracellular transport e.g., due to histamine, hydrogen peroxide [13].

We detected $1.32-1.36 \%$ of the instilled dose of $2 \mathrm{~nm}$ gold in the liver by ICP-MS and $1.9 \pm 0.6 \%$ by NAA in the second experiment. In 4 mice instilled $40 \mathrm{~nm}$ and 4 mice instilled $100 \mathrm{~nm}$ gold particles the liver was completely void of gold. However, in the fifth mouse of the $40 \mathrm{~nm}$ nanoparticles group gold was detected in the liver by both ICP-MS and by AMG. The gold content of the liver of that particular mouse was very high, which suggests airway damage during the instillation and an uptake of gold nanoparticles though the damaged tissue. One mouse in the $100 \mathrm{~nm}$ group had $0.39 \%$ accumulation of the gold dose in the liver. This is probably also due to damage to the airways during the installation.

Our study supports that only small amounts of gold nanoparticles are translocated from lungs $[24,25]$ However, Semmler-Behnke reported significant translocation of smaller $(1.4 \mathrm{~nm})$ gold nanoparticles to the liver $(0.7 \%)$. Similarily, we found that translocation of $2 \mathrm{~nm}$ particles takes place (only 1.3-1.9\%o). However, another group reported significant systemic translocation following inhalation of gold nanoparticles with average diameter of $20 \mathrm{~nm}$. Yu and coworkers detected $4.84 \%$ of the lung concentration in the blood 15 days after exposure [16]. The discrepancy between Yu and coworker's findings and ours could be caused by differences in the surface characteristics of the gold nanoparticles used. It should be noticed, however, that they used rats, not mice, in their study. Also they exposed animals via inhalation, not instillation.

We found that gold could be traced in macrophages in the lungs in all 6 mice 1 hour after they were instilled intratracheally with a single dose of $50 \mu \mathrm{l}$ gold nanoparticles. This proves that the uptake of gold into the lysosome-like organelles of macrophages is a rapid process. To establish the degree of systemic translocation, the livers of the animals were analyzed with AMG and ICP-MS. We have previously found that the liver is the main organ for accumulation of gold nanoparticles, and it is therefore a good probe for the translocation rate [18]. Our data suggest that very small amounts of gold particles $2 \mathrm{~nm}$ or less in size are translocated in normal healthy lungs and whereas there is less translocation of $40 \mathrm{~nm}$ and the 100 nm gold.

The present study shows that: (1) intratracheally instilled colloidal gold nanoparticles are being phagocytized by macrophages of the lungs; (2) translocation of the intratracheally instilled gold nanoparticles to systemic circulation is below detection limits of the used techniques or very low. (3) The translocation of $2 \mathrm{~nm}$ gold nanoparticles is greater than of 40 and $100 \mathrm{~nm}$ ones.

\section{Competing interests}

The authors declare that they have no competing interests.

\section{Authors' contributions}

All authors contributed to execution of the presented work. ES designed the study, acquired and interpreted the data and drafted the manuscript. NRJ aquired and interpreted data. GD was involved in the interpreration of the 
results and drafted the manuscript. MS, UV and AL were involved in the interpretation of the results and reviewed the manuscript. WK was involved in the acquisition of data, interpretation of the results and reviewed the manuscript. HW designed the study, interpreted data and drafted the manuscript.

\section{Acknowledgements}

The technical assistance of Ms Dorete Jensen, Ms Majken Sand, Mr. Albert Meier, and Mr. Michael Guldbrandsen is gratefully acknowledged. We also are indebted to Dr. Dorothea Alber and Gregor Bukalis performing NAA. This work was supported by grants from the Danish Ministry of Health, Research Centre for Environmental Health's Fund, National Research Council Aarhus University, and National Research Centre for the Working Environment NRCWE and the Danielsen foundation.

\section{References}

I. von Klot S, Wölke G, Tuch T, Heinrich J, Dockery DW, Schwartz J, Kreyling WG, Wichmann HE, Peters A: Increased asthma medication use in association with ambient fine and ultrafine particles. Eur Respir J 2002, 20:691-702.

2. von Klot S, Peters A, Aalto P, Bellander T, Berglind N, D'Ippoliti D, Elosua R, Hörmann A, Kulmala M, Lanki T, Löwel H, Pekkanen J, Picciotto S, Sunyer J, Forastiere F: Health Effects of Particles on Susceptible Subpopulations (HEAPSS) Study Group. Ambient air pollution is associated with increased risk of hospital cardiac readmissions of myocardial infarction survivors in five European cities. Circulation 2005, I I 2:3073-9. Erratum in: Circulation 2006, II3: e7I.

3. Ibald-Mulli A, Timonen KL, Peters A, Heinrich J, Wölke G, Lanki T, Buzorius G, Kreyling WG, de Hartog J, Hoek G, ten Brink HM, Pekkanen J: Effects of particulate air pollution on blood pressure and heart rate in subjects with cardiovascular disease: a multicenter approach. Environ Health Perspect 2004, I I 2:369-77.

4. Pope CA: Air pollution and health - good news and bad. N Engl J Med 2004, 35 I: I I32-4.

5. Pope CA, Dockery DW: Health effects of fine particulate air pollution: lines that connect. J Air Waste Manag Assoc 2006, 56:709-42.

6. Pope CA: Mortality effects of longer term exposures to fine particulate air pollution: review of recent epidemiological evidence. Inhal Toxicol 2007, I:33-8.

7. Nemmar A, Hoylaerts MF, Nemery B: Effects of particulate air pollution on hemostasis. Clin Occup Environ Med 2006, 5:865-8I.

8. Oberdörster G, Sharp Z, Atudorei V, Elder A, Gelein R, Lunts A, Kreyling W, Cox C: Extrapulmonary translocation of ultrafine carbon particles following whole- body inhalation exposure of rats. J Toxicol Environ Health A 2002, 65: I53 I-43.

9. Kreyling WG, Semmler M, Erbe F, Mayer P, Takenaka S, Schulz H, Oberdörster $G$, Ziesenis A: Translocation of ultrafine insoluble iridium particles from lung epithelium to extrapulmonary organs is size dependent but very low. J Toxicol Environ Health $A$ 2002, 65:1513-30.

10. Nemmar A, Hoylaerts MF, Hoet PH, Dinsdale D, Smith T, Xu H, Vermylen J, Nemery B: Ultrafine particles affect experimental thrombosis in an in vivo hamster model. Am J Respir Crit Care Med 2002, 166:998-1004.

II. Nemmar A, Hoylaerts MF, Hoet PH, Nemery B: Possible mechanisms of the cardiovascular effects of inhaled particles: systemic translocation and prothrombotic effects. Toxicol Lett 2004, I 49:243-53.

12. Inoue H, Shimada A, Kaewamatawong T, Naota M, Morita T, Ohta Y, Inoue $\mathrm{K}$, Takano $\mathrm{H}$ : Ultrastructural changes of the air-blood barrier in mice after intratracheal instillation of lipopolysaccharide and ultrafine carbon black particles. Exp Toxicol Pathol 2009, 61:51-8.

13. Mühlfeld C, Rothen-Rutishauser B, Blank F, Vanhecke D, Ochs M, Gehr P: Interactions of nanoparticles with pulmonary structures and cellular responses. Am J Physiol Lung Cell Mol Physiol 2008, 294:8I7-29.
14. Kreyling WG, Semmler-Behnke M, Seitz J, Scymczak W, Wenk A, Mayer P, Takenaka S, Oberdörster G: Size dependence of the translocation of inhaled iridium and carbon nanoparticle aggregates from the lung of rats to the blood and secondary target organs. Inhal Toxicol 2009, 21:55-60.

15. Kreyling WG, Semmler-Behnke M, Möller W: Ultrafine particlelung interactions: does size matter? J Aerosol Med 2006, 19:74-83.

16. Yu LE, Yung LL, Ong C, Tan Y, Balasubramaniam KS, Hartono D, Shui G, Wenk MR, Ong W: Translocation and effects of gold nanoparticles after inhalation exposure in rats. Nanotoxicology 2007, I:235-242.

17. Oberdörster G, Sharp Z, Atudorei V, Elder A, Gelein R, Kreyling W, Cox C: Translocation of inhaled ultrafine particles to the brain. Inhal Toxicol 2004, 16:437-45.

18. Elder A, Gelein R, Silva V, Feikert T, Opanashuk L, Carter J, Potter R, Maynard A, Ito Y, Finkelstein J, Oberdörster G: Translocation of inhaled ultrafine manganese oxide particles to the central nervous system. Environ Health Perspect 2006, I I 4: I 172-8. Erratum in: Environ Health Perspect 2006, I I 4: I 178.

19. Shukla R, Bansal V, Chaudhary M, Basu A, Bhonde RR, Sastry M: Biocompatibility of gold nanoparticles and their endocytotic fate inside the cellular compartment: a microscopic overview. Langmuir 2005, 21:10644-54.

20. Danscher G, Nörgaard JO: Light microscopic visualization of colloidal gold on resin- embedded tissue. J Histochem Cytochem 1983, 31:1394-8.

21. Penn SG, He L, Natan MJ: Nanoparticles for bioanalysis. Curr Opin Chem Biol 2003, 7:609-15.

22. Bergen JM, von Recum HA, Goodman TT, Massey AP, Pun SH: Gold nanoparticles as a versatile platform for optimizing physicochemical parameters for targeted drug delivery. Macromol Biosci 2006, 6:506-16

23. Hainfeld JF, Slatkin DN, Focella TM, Smilowitz HM: Gold nanoparticles: a new X-ray contrast agent. Br J Radiol 2006, 79:248-53.

24. Hainfeld JF, Dilmanian FA, Slatkin DN, Smilowitz HM: Radiotherapy enhancement with gold nanoparticles. J Pharm Pharmacol 2008, 60:977-85.

25. Takenaka S, Karg E, Kreyling WG, Lentner B, Möller W, BehnkeSemmler M, Jennen L, Walch A, Michalke B, Schramel P, Heyder J, Schulz H: Distribution pattern of inhaled ultrafine gold particles in the rat lung. Inhal Toxicol 2006, 18:733-40.

26. Semmler-Behnke M, Kreyling WG, Lipka J, Fertsch S, Wenk A, Takenaka S, Schmid G, Brandau W: Biodistribution of I.4- and I 8-nm gold particles in rats. Small 2008, 4:2108-II.

27. Sadauskas E, Wallin H, Stoltenberg M, Vogel U, Doering P, Larsen A, Danscher G: Kupffer cells are central in the removal of nanoparticles from the organism. Part Fibre Toxicol 2007, 4:10.

28. Sadauskas E, Danscher G, Stoltenberg M, Vogel U, Larsen A, Wallin $\mathrm{H}$ : Protracted elimination of gold nanoparticles from mouse liver. Nanomedicine 2009, 5:162-9.

29. Danscher G, Stoltenberg M: Silver enhancement of quantum dots resulting from (I) metabolism of toxic metals in animals and humans, (2) in vivo, in vitro and immersion created zinc-sulphur/zinc-selenium nanocrystals, (3) metal ions liberated from metal implants and particles. Prog Histochem Cytochem 2006, 4I:57-I39.

30. Lippmann M, Yeates DB, Albert RE: Deposition, retention, and clearance of inhaled particles. Br Jnd Med 1980, 37:337-62

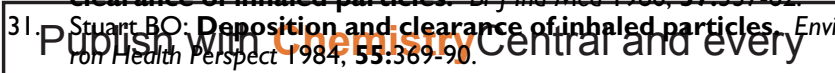

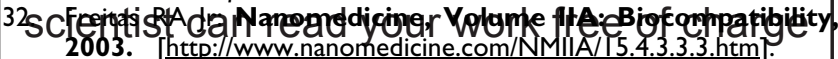
"Open access provides opportunities to our

colleagues in other parts of the globe, by allowing anyone to view the content free of charge."

W. Jeffery Hurst, The Hershey Company.

- available free of charge to the entire scientific community

- peer reviewed and published immediately upon acceptance

- cited in PubMed and archived on PubMed Central

- yours - you keep the copyright

Submit your manuscript here:

http://www.chemistrycentral.com/manuscript/
Chemistry Central 